\title{
Efficient and Convenient Synthesis of
}

\section{1,8-Dioxodecahydroacridine Derivatives Using Cu-Doped ZnO Nanocrystalline Powder as a Catalyst under Solvent-Free Conditions}

\author{
Heshmatollah Alinezhad and Sahar Mohseni Tavakkoli \\ Faculty of Chemistry, University of Mazandaran, Babolsar, Iran \\ Correspondence should be addressed to Heshmatollah Alinezhad; heshmat@umz.ac.ir
}

Received 25 August 2013; Accepted 17 September 2013

Academic Editors: L. D’Accolti and L. Hadjiarapoglou

Copyright (C) 2013 H. Alinezhad and S. Mohseni Tavakkoli. This is an open access article distributed under the Creative Commons Attribution License, which permits unrestricted use, distribution, and reproduction in any medium, provided the original work is properly cited.

A simple and convenient one-step method for synthesis of acridines and their derivatives from condensation of aromatic aldehydes, cyclic diketones, and aryl amines using $\mathrm{Cu}$-doped $\mathrm{ZnO}$ nanocrystalline powder as a catalyst is reported. The present protocol provides several advantages such as good yields, short reaction time, easy workup, and simplicity in operation.

\section{Introduction}

In recent years, an increasing interest has been focused on the synthesis of 1,4-dihydropyridine compounds owing to their significant biological activities [1]. Substituted acridines have been used as antimalarials [2] for many years quite successfully and several of them have exhibited excellent results in chemotherapy of cancer [3-6]. These derivatives are frequently used in industry, especially for the production of dyes [7, 8]. Beside these properties, analogues of acridine have also been shown to have very long lasting efficiencies and have interesting electrochemical behavior $[9,10]$ of heterocyclic compounds and in the interaction with DNA [11].

Some methods are available in the literature for the synthesis of acridine derivatives containing 1,4-dihydropyridines, from dimedone, aldehyde, and different nitrogen sources like urea [12], methyl amine [13], and different anilines or ammonium acetate [14] via traditional heating in organic solvents in the presence of triethylbenzylammonium chloride (TEBAC) [15], $p$-dodecylbenzenesulfonic acid (DBSA) [16], Proline [17], Amberlyst-15 [18], ammonium chloride, $\mathrm{Zn}(\mathrm{OAc})_{2} \cdot \mathrm{H}_{2} \mathrm{O}$ or L-proline [19], and/or under solvent-free conditions such as under microwave irradiation [20-22], sulfonic acid functionalized silica [23], $\mathrm{ZnO}$ nanoparticles [24], and nano- $\mathrm{Fe}_{3} \mathrm{O}_{4}$ [25] and using ionic liquids $[26,27]$ such as 1-methylimidazolium trifluoroacetate ([Hmim]TFA) [28] and Bronsted acidic imidazolium salts containing perfluoroalkyl tails [29]. Furthermore, some of these procedures suffer from other disadvantages, including the requirement for an expensive catalyst or the use of an excess of catalyst. To avoid these limitations and to improve the reaction conditions available for the synthesis of 1,8dioxodecahydroacridines, the discovery of new methodologies using new heterogeneous and reusable catalysts is still in demand.

$\mathrm{ZnO}$ is considered to be one of the most important oxide materials owing to its unique features and wide range of technologically important applications. Moreover,it is cheap and environmentally friendly as compared to other metal oxides. Due to these properties, it has found potential applications in several fields such as gas sensors [30], solar cells [31], varistors [32], light emitting devices [33], photocatalyst [34], antibacterial activity [35], and cancer treatment [36]. $\mathrm{ZnO}$ lacks center of symmetry, which makes it beneficial for use in actuators and piezoelectric transducers. Properties of $\mathrm{ZnO}$ can be tuned according to the research interest, by doping with various metal atoms to suit specific needs and applications. The metal doping induces drastic changes 

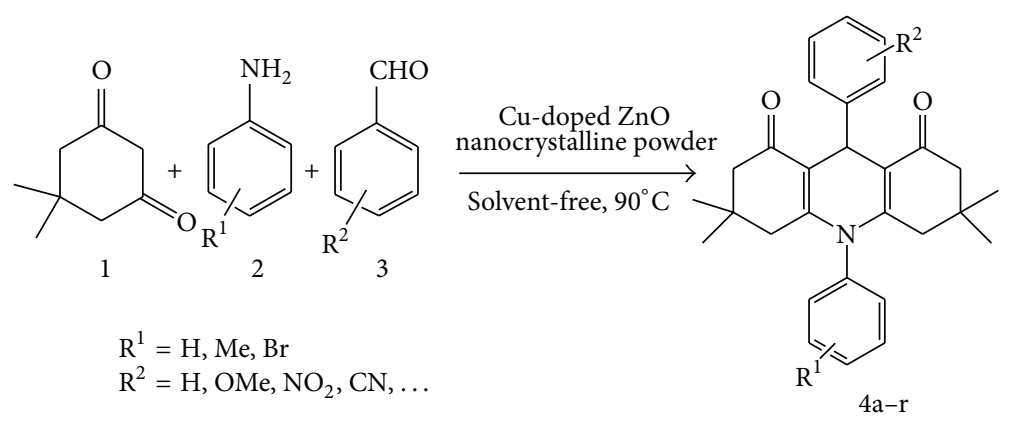

Scheme 1: The synthesis of 1,8-dioxodecahydroacridines in solvent-free conditions.

in optical, electrical, and magnetic properties of $\mathrm{ZnO}$ by altering its electronic structure. Many authors have reported the changes induced by incorporation of transition metal ions into $\mathrm{ZnO}$ lattice [37-39]. albeit the large number of reports on transition metal-doped $\mathrm{ZnO}$ system, very less work is done on $\mathrm{Cu}$-doped $\mathrm{ZnO}$. Substitution of copper into the $\mathrm{ZnO}$ lattice has been shown to improve properties such as photocatalytic activity, gas sensitivity, and magnetic semiconductivity [40-42].

In continuation of our studies in developing efficient, simple, and environmentally benign methodologies for organic synthesis, we reveal herein the synthesis of $N$-substituted decahydroacridine-1,8-diones using $\mathrm{Cu}$-doped $\mathrm{ZnO}$ nanocrystalline powder as a catalyst under solvent-free condition (Scheme 1).

\section{Materials and Methods}

2.1. General. All materials were purchased from Merck. The reactions were monitored by TLC using silica gel plates, and the products were purified by flash column chromatography on silica gel (Merck, 230-400 mesh) and were identified by comparison of their spectra $\left({ }^{1} \mathrm{HNMR}\right.$ and $\left.{ }^{13} \mathrm{CNMR}\right)$ and physical data with those of the authentic samples. ${ }^{1} \mathrm{H}$ NMR and ${ }^{13} \mathrm{C}$ NMR spectra were recorded with Brucker DRX500 AVANCE (400 MHz) spectrometers, using $\mathrm{CDCl}_{3}$ as solvent. The morphology and elemental composition were characterized by a digital microscopy imaging scanning equipment VEGA 3 SB (TESCAN Co., s.r.o., Brno, Czech Republic) and energy dispersive X-ray spectrometer (EDS) attached to the SEM instrument with the operating voltage of $15 \mathrm{kV}$.

2.2. Synthesis of Cu-Doped $Z n O$ Nanocrystalline Powder. Synthesis of $\mathrm{Zn}_{1-x} \mathrm{Cu}_{x} \mathrm{O}$ (1\% Cu-doped) nanopowder was carried out using the same technique followed by Cadar et al. [43] with some modifications after optimization of reaction conditions. The targets in the experiment were specifically designed using high purity of zinc nitrate hexahydrate (99.99\%) and copper sulfate pentahydrate (99\%) powders. The copper-doped $\mathrm{ZnO}$ catalyst was prepared by a two-step procedure: (1) preparation of precursor by coprecipitation method; (2) formation of $\mathrm{Cu} / \mathrm{ZnO}$ nanopowder by thermal decomposition. The method has been considered to be fast,
TABLE 1: Optimization of the reaction conditions ${ }^{\mathrm{a}}$.

\begin{tabular}{lccc}
\hline Entry & Solvent & Time $(\mathrm{h})$ & Yield $(\%)^{\mathrm{b}}$ \\
\hline 1 & Ethanol & 6 & 30 \\
2 & $\mathrm{H}_{2} \mathrm{O}$ & 5 & 30 \\
3 & $\mathrm{CH}_{2} \mathrm{Cl}_{2}$ & 4 & 20 \\
4 & $\mathrm{DMF}$ & 6 & 40 \\
5 & - & 1.5 & 90 \\
\hline
\end{tabular}

${ }^{\mathrm{a}}$ Reactions were carried out with dimedone, aniline, and benzaldehyde in $2: 1: 1$ molar ratio.

${ }^{\mathrm{b}}$ Yields refer to isolated pure products.

TABLE 2: Effect of amount of catalyst on the synthesis of $N$ substituted Decahydroacridine-1,8-diones ${ }^{\mathrm{a}}$.

\begin{tabular}{lccc}
\hline Entry & Catalyst $(\mathrm{mol} \%)$ & Time $(\mathrm{h})$ & Yield $(\%)^{\mathrm{b}}$ \\
\hline 1 & 5 & 3.5 & 90 \\
2 & 10 & 1.5 & 90 \\
3 & 15 & 1.5 & 90 \\
\hline
\end{tabular}

${ }^{a}$ Reactions were carried out with dimedone, aniline, and benzaldehyde with molar ratio of $2: 1: 1$.

${ }^{\mathrm{b}}$ Yields refer to isolated pure products.

simple, and inexpensive, allowing for the production of fine, homogeneous crystalline powders without the risk of contamination.

The stoichiometric quantities of zinc and copper salts were dissolved in $100 \mathrm{~mL}$ deionized double distilled water (solution A). Separately, a solution was prepared by dissolving appropriate amounts of sodium hydroxide and sodium carbonate in deionized double distilled water (solution $\mathrm{B}$ ). The solution $\mathrm{A}$ was heated to $85^{\circ} \mathrm{C}$ and the solution $\mathrm{B}$ was mixed dropwise into this solution with constant stirring. During the whole process, temperature was maintained at $85^{\circ} \mathrm{C}$. This mixing was done for $1 \mathrm{~h}$ while refluxing through water condenser $85^{\circ} \mathrm{C}$. Final solution was allowed to cool at room temperature and greenish precipitate that formed was washed three times with $20 \mathrm{~mL}$ deionized water in order to remove unnecessary impurities and dried overnight at $50^{\circ} \mathrm{C}$ under vacuum. Finally, the precursors were calcined at a temperature of $450^{\circ} \mathrm{C}$ for $90 \mathrm{~min}$ in the muffle furnace under air atmosphere to obtain the nanocrystalline $\mathrm{Cu} / \mathrm{ZnO}$ powder. 
TABLE 3: Synthesis of $N$-substituted decahydroacridine-1,8-diones using $\mathrm{Cu}$-doped $\mathrm{ZnO}$ nanocrystalline powder (10 mol\%) as a catalyst in solvent-free condition ${ }^{\mathrm{a}}$.

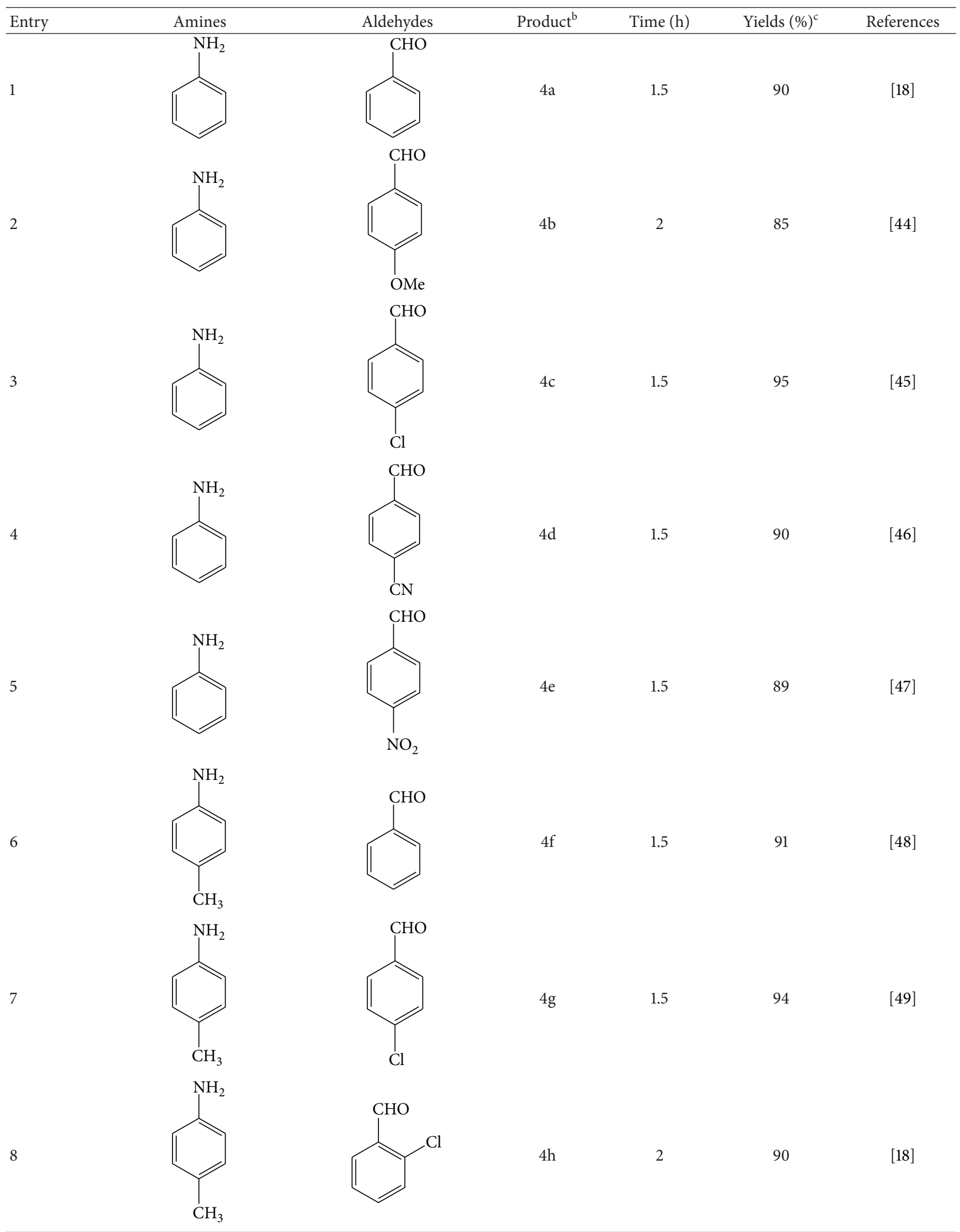


TABLE 3: Continued.

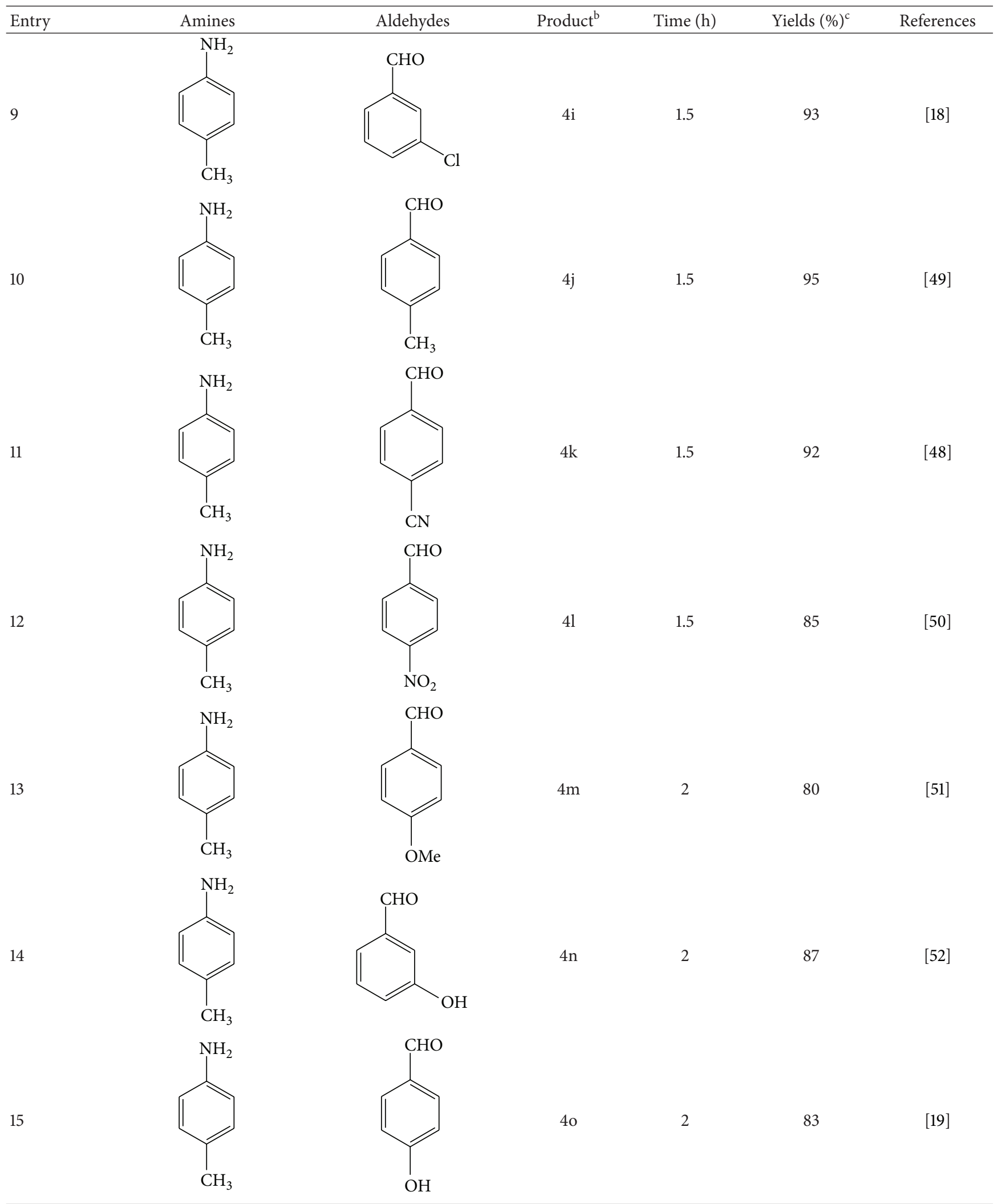


TABLe 3: Continued.

Entry

Reactions were carried out with dimedone, amine, and benzaldehyde in $2: 1: 1$ molar ratio.

${ }^{\mathrm{b}}$ products were characterized with ${ }^{1} \mathrm{H},{ }^{13} \mathrm{C}-\mathrm{NMR}, \mathrm{mp}$.

${ }^{\mathrm{c}}$ Yields refer to isolated pure products.

Figure 1 shows scanning electron micrograph of nanocrystalline $\mathrm{Zn}_{1-x} \mathrm{Cu}_{x} \mathrm{O}$ sample. In order to confirm the presence of $\mathrm{Cu}$ in the synthesized $\mathrm{ZnO}$ nanoparticles, the compositional analysis and purity of the as-synthesized nanocatalyst was obtained using EDS. Figure 2 shows the representative EDX spectra of nanocrystalline sample that the estimated amount of $\mathrm{Cu}$ dopant was nearly $1 \%$. From the similarity of the $\mathrm{Zn}$ and $\mathrm{Cu}$ peak intensity line traces, it is clear that after the synthesis process, zinc and copper were homogenously distributed inside the nanoparticle.

2.3. General Experimental Procedure for N-Substituted Decahydroacridine-1,8-diones Formation Catalyzed by $\mathrm{Cu}$-Doped $\mathrm{ZnO}$ Nanocrystalline Powder (Table 3, Entry 1). A mixture of dimedone $1(2 \mathrm{mmol})$, aromatic amine $2(1 \mathrm{mmol})$, aromatic benzaldehyde $3(1 \mathrm{mmol})$, and $10 \mathrm{~mol} \%$ of $\mathrm{Cu}$-doped $\mathrm{ZnO}$ nanocrystalline powder was heated in an oil bath at $90^{\circ} \mathrm{C}$ for 1.5 or $2 \mathrm{~h}$. The reaction process was monitored by TLC ( $\mathrm{n}$ Hexane: EtOAc, 1:1). Upon completion of the transformation, the reaction mixture was cooled to room temperature and hot ethanol $(15 \mathrm{~mL})$ was added. This resulted in the precipitation of the catalyst, which was collected by filtration. The filtrate was distilled to dryness to give the crude product, which was recrystallized from a mixture of $\mathrm{EtOH}$ and $\mathrm{H}_{2} \mathrm{O}$ to give compounds 4 in high to excellent yields (Scheme 1).

\section{Results and Discussion}

At first, to optimize the reaction condition, we studied the reaction of dimedone $(2 \mathrm{mmol})$, aniline $(1 \mathrm{mmol})$, and benzaldehyde $(1 \mathrm{mmol})$ as model compounds in the presence of $\mathrm{Cu}$-doped $\mathrm{ZnO}$ nanocrystalline powder $(10 \mathrm{~mol} \%)$ as a catalyst in solvent-free condition. We evaluated the effect of different solvents such as ethanol, $\mathrm{H}_{2} \mathrm{O}, \mathrm{DMF}, \mathrm{CH}_{2} \mathrm{Cl}_{2}$, and solvent-free condition on the reaction rate under the same reaction conditions. Solvent-free condition afforded the products in higher yield and shorter reaction time (Table 1).

We next investigated the other amounts of $\mathrm{Cu}$-doped $\mathrm{ZnO}$ nanocrystalline powder (5 and $15 \mathrm{~mol} \%$ ) for this reaction. The optimum yield of the $\mathrm{N}$-substituted decahydroacridine-1,8-diones was obtained when $10 \mathrm{~mol} \%$ of $\mathrm{Cu}$-doped $\mathrm{ZnO}$ nanocrystalline powder was used (Table 2).

Therefore, in an optimized reaction condition dimedone ( $2 \mathrm{mmol})$, amine $(1 \mathrm{mmol})$, and benzaldehyde $(1 \mathrm{mmol})$ in an oil bath at $90^{\circ} \mathrm{C}$ were mixed with $\mathrm{Cu}$-doped $\mathrm{ZnO}$ nanocrystalline powder (10 mol\%) for 1.5 or $2 \mathrm{~h}$ (Table 3 ).

Subsequently, a variety of $N$-substituted decahydroacridine-1,8-diones were prepared from dimedone, various benzaldehyde derivatives, aniline derivatives, and benzylamine using the optimized reaction conditions and the results are summarized in Table 3.

As shown in Table 3 when the electron withdrawing substituents are present in benzaldehyde, the reaction rate increases, whereas the effect is reversed in the case of benzaldehyde with strong electron-donating substituents such as $-\mathrm{OMe}$ and $-\mathrm{OH}$, of course with lower yields (entries 2, 13, 14 , and 15). Orthosubstituted benzaldehyde also required relatively long reaction time towards para- and metasubstituted benzaldehydes (entries 7, 8,9), because of its steric effect.

A plausible mechanism for the formation of the 1,8-dioxodecahydroacridine products using $\mathrm{Cu}$-doped $\mathrm{ZnO}$ nanocrystalline powder as a catalyst has been depicted in Scheme 2 . 


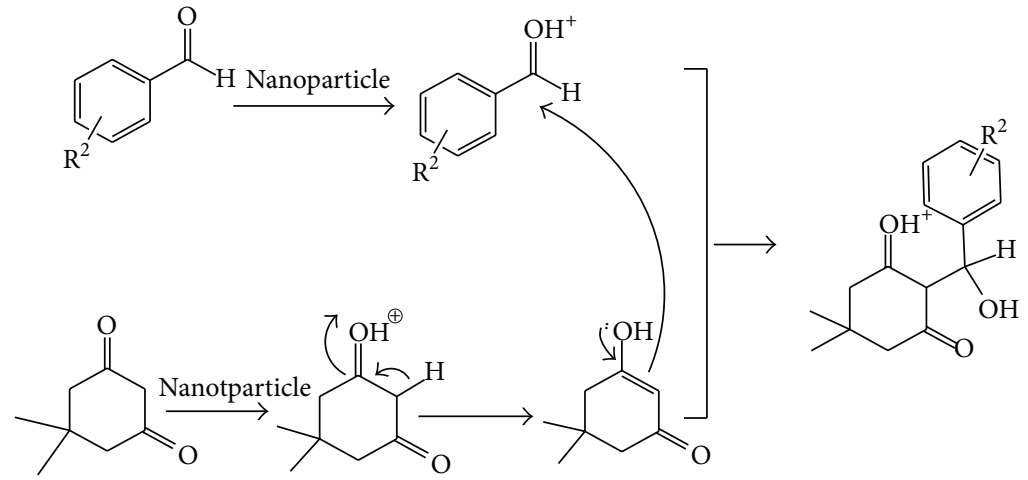

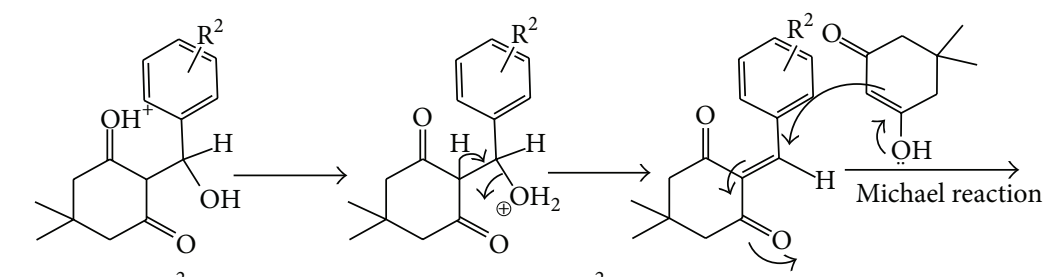

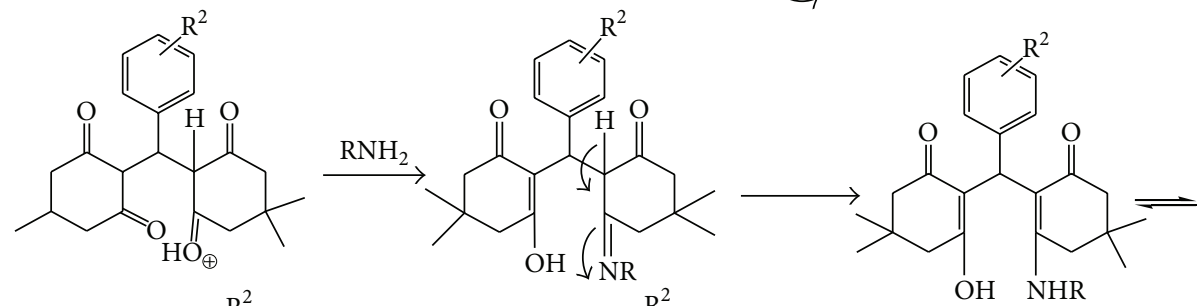

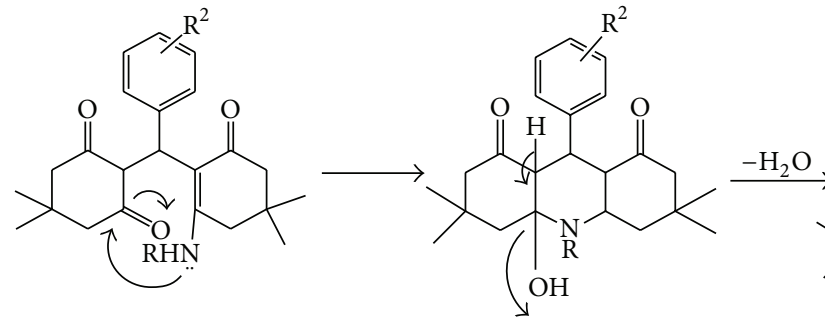<smiles>[R]C1=C2C(=O)CC(C)(C)CC2=C([R])C(=O)CC(C)(C)C1</smiles>

$\mathrm{R}: \mathrm{ph}$

SCHEME 2: The proposed mechanism of synthesis of 1,8-dioxodecahydroacridines.

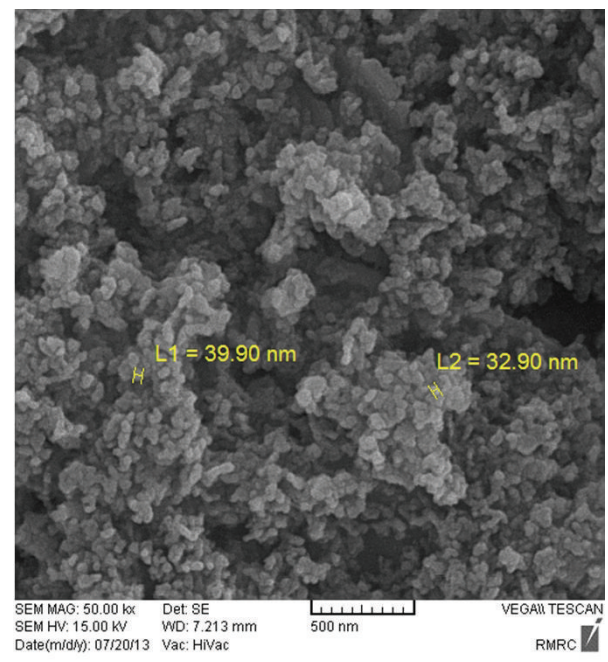

Figure 1: SEM photo of $1 \% \mathrm{Cu}$-doped $\mathrm{ZnO}$ nanocrystalline powder.

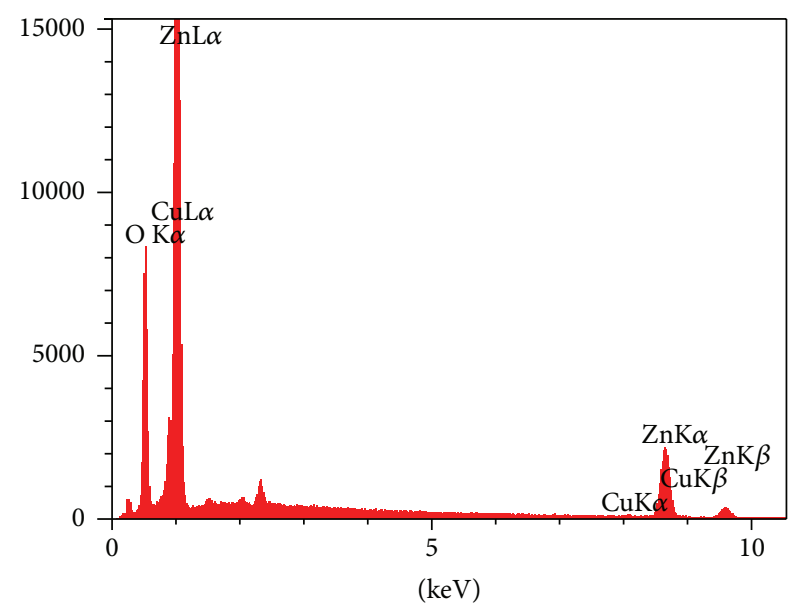

FIGURE 2: Representative EDX spectra of $1 \% \mathrm{Cu}$-doped nanocatalyst sample. 
We propose that the nanoparticle induces the polarization of the carbonyl groups and facilitates the formation of the intermediates that subsequently react together to give the final products $4 \mathrm{a}-4 \mathrm{r}$.

\section{Conclusion}

We have developed a new catalytic method for synthesis of 1,8-dioxodecahydroacridines using $\mathrm{Cu}$-doped $\mathrm{ZnO}$ nanocrystalline powder as a catalyst in solvent-free condition by one-pot three-component condensation of aromatic aldehydes, dimedone, and aromatic and aliphatic amines. The simple experimental, workup procedure and catalyst preparation, high to excellent yields and using catalytic amount of $\mathrm{Cu}$-doped $\mathrm{ZnO}$ nanocrystalline powder, are notable advantages of the method.

\section{Acknowledgment}

The financial support of this work from the Research Council of University of Mazandaran is gratefully acknowledged.

\section{References}

[1] R. Shan, C. Velazquez, and E. E. Knaus, "Syntheses, calcium channel agonist-antagonist modulation activities, and nitric oxide release studies of nitrooxyalkyl 1,4-dihydro-2,6-dimethyl-3-nitro-4-(2,1,3-benzoxadiazol-4-yl) pyridine-5-carboxylate racemates, enantiomers, and diastereomers," Journal of Medicinal Chemistry, vol. 47, no. 1, pp. 254-261, 2004.

[2] S. Girault, P. Grellier, A. Berecibar et al., "Antimalarial, antitrypanosomal, and antileishmanial activities and cytotoxicity of bis(9-amino-6-chloro-2- methoxyacridines): influence of the linker," Journal of Medicinal Chemistry, vol. 43, no. 14, pp. 26462654, 2000.

[3] W. M. Cholody, B. Horowska, J. Paradziej-Lukowicz, S. Martelli, and J. Konopa, "Structure-activity relationship for antineoplastic imidazoacridinones: synthesis and antileukemic activity in vivo," Journal of Medicinal Chemistry, vol. 39, no. 5, pp. 10281032, 1996.

[4] T. K. Chen, R. Fico, and E. S. Canellakis, "Diacridines, bifunctional intercalators: chemistry and antitumor activity," Journal of Medicinal Chemistry, vol. 21, no. 9, pp. 868-874, 1978.

[5] W. A. Denny, G. J. Atwell, B. C. Baguley, and L. P. G. Wakelin, "Potential antitumor agents. 44. Synthesis and antitumor activity of new classes of diacridines: importance of linker chain rigidity for DNA binding kinetics and biological activity," Journal of Medicinal Chemistry, vol. 28, no. 11, pp. 1568-1574, 1985.

[6] G. W. Rewcastle, G. J. Atwell, D. Chambers, B. C. Baguley, and W. A. Denny, "Potential antitumor agents. 46. Structureactivity relationships for acridine monosubstituted derivatives of the antitumor agent $\mathrm{N}$-[2-(dimethylamino)ethyl]-9aminoacridine-4-carboxamide," Journal of Medicinal Chemistry, vol. 29, no. 4, pp. 472-477, 1986.

[7] B. D. Tilak and N. R. Ayyangar, "Chapter VIII. Acridine Dyes," in Chemistry of Heterocyclic Compounds, vol. 9, pp. 579-613, 2nd edition, 1973.

[8] A. Albert, The Acridines, Edward Arnold Publications, London, UK, 1966.
[9] N. Srividya, P. Ramamurthy, P. Shanmugasundaram, and V. T. Ramakrishnan, "Synthesis, characterization, and electrochemistry of some acridine-1,8-dione dyes," Journal of Organic Chemistry, vol. 61, no. 15, pp. 5083-5089, 1996.

[10] F. Dollé, F. Hinnen, H. Valette et al., "Synthesis of two optically active calcium channel antagonists labelled with carbon-11 for in vivo cardiac PET imaging," Bioorganic and Medicinal Chemistry, vol. 5, no. 4, pp. 749-764, 1997.

[11] Z. Hernandez-Gallegos, P. A. Lehmann, E. Hong, F. Posadas, and E. Hernandez-Gallegos, "Novel halogenated 1,4-dihydropyridines: synthesis, bioassay, microsomal oxidation and structure-activity relationships," European Journal of Medicinal Chemistry, vol. 30, no. 5, pp. 355-364, 1995.

[12] A. A. Bakibaev, V. D. Fillimonov, and E. S. Nevgodova, "Ureas in the organic synthesis. Part 6: reactions of 1,3-dicarbonyls with azomethines and urea in DMSO as a method for the synthesis of aryl-substituted acridine 1, 8-diones and 1, 4-dihydropyridines," Russian Journal of Organic Chemistry, vol. 27, no. 7, pp. 1519$1524,1991$.

[13] G.-P. Hua, S.-J. Tu, X.-T. Zhu et al., "One-pot synthesis of 10methyl-1,2,3,4,5,6,7,8,9,10-decahydroacridine-1,8- dione derivatives under microwave heating without catalyst," Chinese Journal of Chemistry, vol. 23, no. 12, pp. 1646-1650, 2005.

[14] N. Martin, M. Quinteiro, C. Seoane et al., "Synthesis of conformational study of acridine derivatives related to 1,4dihydropyridines," Journal of Heterocyclic Chemistry, vol. 32, no. 1, pp. 235-238, 1995.

[15] X.-S. Wang, D.-Q. Shi, Y.-F. Zhang, S.-H. Wang, and S.-J. Tu, "Synthesis of 9-arylpolyhydroacridine in water catalyzed by triethylbenzylammonium chloride (TEBA)," Chinese Journal of Organic Chemistry, vol. 24, no. 4, pp. 430-432, 2004.

[16] T.-S. Jin, J.-S. Zhang, T.-T. Guo, A.-Q. Wang, and T.-S. Li, “Onepot clean synthesis of 1,8-dioxo-decahydroacridines catalyzed by $p$-dodecylbenezenesulfonic acid in aqueous media," Synthesis, vol. 2004, no. 12, pp. 2001-2005, 2004.

[17] K. Venkatesan, S. S. Pujari, and K. V. Srinivasan, "Prolinecatalyzed simple and efficient synthesis of 1,8-dioxo- decahydroacridines in aqueous ethanol medium," Synthetic Communications, vol. 39, no. 2, pp. 228-241, 2009.

[18] B. Das, P. Thirupathi, I. Mahender, V. S. Reddy, and Y. K. Rao, "Amberlyst-15: an efficient reusable heterogeneous catalyst for the synthesis of 1,8-dioxo-octahydroxanthenes and 1,8-dioxodecahydroacridines," Journal of Molecular Catalysis A, vol. 247, no. 1-2, pp. 233-239, 2006.

[19] S. Balalaie, F. Chadegani, F. Darviche, and H. R. Bijanzadeh, "One-pot synthesis of 1,8-dioxo-decahydroacridine derivatives in aqueous media," Chinese Journal of Chemistry, vol. 27, no. 10, pp. 1953-1956, 2009.

[20] S.-J. Tu, C.-B. Miao, Y. Gao, Y.-J. Feng, and J.-C. Feng, "Microwave-prompted reaction of cinnamonitrile derivatives with 5,5-dimethyl-1,3-cyclohexanedione," Chinese Journal of Chemistry, vol. 20, no. 7, pp. 703-706, 2002.

[21] X.-S. Wang, D.-Q. Shi, S.-H. Wang, and S.-J. Tu, "Synthesis of 9Aryl-10-(4-methylphenyl)polyhydroacridine under microwave irradiation," Chinese Journal of Organic Chemistry, vol. 23, no. 11, pp. 1291-1293, 2003.

[22] Z.-Q. Tang, Y. Chen, C.-N. Liu, K.-Y. Cai, and S.-J. Tu, "A green procedure for the synthesis of 1,8-dioxodecahydroacridine derivatives under microwave irradiation in aqueous media 
without catalyst," Journal of Heterocyclic Chemistry, vol. 47, no. 2, pp. 363-367, 2010.

[23] G. M. Ziarani, A. Badiei, M. Hassanzadeh, and S. Mousavi, "Synthesis of 1,8-dioxo-decahydroacridine derivatives using sulfonic acid functionalized silica $\left(\mathrm{SiO}_{2}-\mathrm{Pr}-\mathrm{SO}_{3} \mathrm{H}\right)$ under solvent free conditions," Arabian Journal of Chemistry, 2011.

[24] J. Safaei-Ghomi, M. A. Ghasemzadeh, and S. Zahedi, "ZnO nanoparticles: a highly effective and readily recyclable catalyst for the one-pot synthesis of 1,8 -dioxo-decahydroacridine and 1, 8-dioxooctahydro-xanthene derivatives," Journal of the Mexican Chemical Society, vol. 57, no. 1, pp. 1-7, 2013.

[25] M. A. Ghasemzadeh, J. Safaei-Ghomi, and H. Molaei, " $\mathrm{Fe}_{3} \mathrm{O}_{4}$ nanoparticles: as an efficient, green and magnetically reusable catalyst for the one-pot synthesis of 1, 8-dioxo-decahydroacridine derivatives under solvent-free conditions," Comptes Rendus Chimie, vol. 15, no. 11-12, pp. 969-974, 2012.

[26] Y.-L. Li, M.-M. Zhang, X.-S. Wang et al., "One pot three component synthesis of 9-arylpolyhydroacridine derivatives in an ionic liquid medium," Journal of Chemical Research, vol. 2005, no. 9, pp. 600-602, 2005.

[27] G.-W. Wang, J.-J. Xia, C.-B. Miao, and X.-L. Wu, "Environmentally friendly and efficient synthesis of various 1,4-dihydropyridines in pure water," Bulletin of the Chemical Society of Japan, vol. 79, no. 3, pp. 454-459, 2006.

[28] M. Dabiri, M. Baghbanzadeh, and E. Arzroomchilar, "1-Methylimidazolium triflouroacetate ([Hmim]TFA): an efficient reusable acidic ionic liquid for the synthesis of 1,8-dioxo-octahydroxanthenes and 1,8-dioxo-decahydroacridines," Catalysis Communications, vol. 9, no. 5, pp. 939-942, 2008.

[29] W. Shen, L.-M. Wang, H. Tian, J. Tang, and J.-J. Yu, “Brønsted acidic imidazolium salts containing perfluoroalkyl tails catalyzed one-pot synthesis of 1,8-dioxo-decahydroacridines in water," Journal of Fluorine Chemistry, vol. 130, no. 6, pp. 522$527,2009$.

[30] F. Meng, J. Yin, Y.-Q. Duan, Z.-H. Yuan, and L.-J. Bie, “Coprecipitation synthesis and gas-sensing properties of $\mathrm{ZnO}$ hollow sphere with porous shell," Sensors and Actuators B, vol. 156, no. 2, pp. 703-708, 2011.

[31] Z. Liu, C. Liu, J. Ya, and E. Lei, "Controlled synthesis of $\mathrm{ZnO}$ and $\mathrm{TiO}_{2}$ nanotubes by chemical method and their application in dye-sensitized solar cells," Renewable Energy, vol. 36, no. 4, pp. 1177-1181, 2011.

[32] K. Hembram, D. Sivaprahasam, and T. N. Rao, "Combustion synthesis of doped nanocrystalline $\mathrm{ZnO}$ powders for varistors applications," Journal of the European Ceramic Society, vol. 31, no. 10, pp. 1905-1913, 2011.

[33] H. Kim, A. Piqué, J. S. Horwitz et al., "Effect of aluminum doping on zinc oxide thin films grown by pulsed laser deposition for organic light-emitting devices," Thin Solid Films, vol. 377378, pp. 798-802, 2000.

[34] K. C. Barick, S. Singh, M. Aslam, and D. Bahadur, "Porosity and photocatalytic studies of transition metal doped $\mathrm{ZnO}$ nanoclusters," Microporous and Mesoporous Materials, vol. 134, no. 1-3, pp. 195-202, 2010.

[35] K. Rekha, M. Nirmala, M. G. Nair, and A. Anukaliani, "Structural, optical, photocatalytic and antibacterial activity of zinco xide and manganese doped zinc oxide nanoparticles," Physica $B$, vol. 405, no. 15, pp. 3180-3185, 2010.
[36] H. Zhang, B. Chen, H. Jiang, C. Wang, H. Wang, and X. Wang, "A strategy for $\mathrm{ZnO}$ nanorod mediated multi-mode cancer treatment," Biomaterials, vol. 32, no. 7, pp. 1906-1914, 2011.

[37] S. V. Bhat and F. L. Deepak, “Tuning the bandgap of $\mathrm{ZnO}$ by substitution with $\mathrm{Mn}^{2+}, \mathrm{Co}^{2+}$ and $\mathrm{Ni}^{2+}$," Solid State Communications, vol. 135, no. 6, pp. 345-347, 2005.

[38] S. Deka and P. A. Joy, "Synthesis and magnetic properties of Mn doped ZnO nanowires," Solid State Communications, vol. 142, no. 4, pp. 190-194, 2007.

[39] C. Jing, Y. Jiang, W. Bai, J. Chu, and A. Liu, "Synthesis of Mndoped $\mathrm{ZnO}$ diluted magnetic semiconductors in the presence of ethyl acetoacetate under solvothermal conditions," Journal of Magnetism and Magnetic Materials, vol. 322, no. 16, pp. 23952400, 2010.

[40] Y. S. Sonawane, K. G. Kanade, B. B. Kale, and R. C. Aiyer, "Electrical and gas sensing properties of self-aligned copperdoped zinc oxide nanoparticles," Materials Research Bulletin, vol. 43, no. 10, pp. 2719-2726, 2008.

[41] D. B. Buchholz, R. P. H. Chang, J. H. Song, and J. B. Ketterson, "Room-temperature ferromagnetism in $\mathrm{Cu}$-doped $\mathrm{ZnO}$ thin films," Applied Physics Letters, vol. 87, no. 12, 2005.

[42] K. G. Kanade, B. B. Kale, J.-O. Baeg et al., "Self-assembled aligned $\mathrm{Cu}$ doped $\mathrm{ZnO}$ nanoparticles for photocatalytic hydrogen production under visible light irradiation," Materials Chemistry and Physics, vol. 102, no. 1, pp. 98-104, 2007.

[43] O. Cadar, C. Roman, L. Gagea, I. Cernica, and A. Matei, "Synthesis, characterization and optimum reaction conditions for nanostructured zinc oxide," Studia Universitatis BabesBolyai Chemia, vol. 4, no. 1, pp. 116-124, 2009.

[44] M. Kidwai and D. Bhatnagar, "Ceric ammonium nitrate (CAN) catalyzed synthesis of N-substituted decahydroacridine-1,8diones in PEG," Tetrahedron Letters, vol. 51, no. 20, pp. 2700 2703, 2010.

[45] M. Hong and G. Xiao, "FSG-Hf(NPf2)4 catalyzed, environmentally benign synthesis of 1,8 -dioxo-decahydroaridines in waterethanol," Journal of Fluorine Chemistry, vol. 144, pp. 7-9, 2012.

[46] J. J. Xia and K. H. Zhang, "Synthesis of N-substituted acridinediones and polyhydroquinoline derivatives in refluxing water," Molecules, vol. 17, no. 5, pp. 5339-5345, 2012.

[47] H. Luo, Y. Kang, H. Nie, and L. Yang, " $\mathrm{Fe}^{3+}$-montmorillonite: an efficient solid catalyst for one-pot synthesis of decahydroacridine derivatives," Journal of the Chinese Chemical Society, vol. 55, no. 6, pp. 1280-1285, 2008.

[48] Y.-B. Shen and G.-W. Wang, "Solvent-free synthesis of xanthenediones and acridinediones," Arkivoc, vol. 2008, no. 16, pp. $1-8,2008$.

[49] W. Shen, L.-M. Wang, H. Tian, J. Tang, and J.-J. Yu, "Brønsted acidic imidazolium salts containing perfluoroalkyl tails catalyzed one-pot synthesis of 1,8-dioxo-decahydroacridines in water," Journal of Fluorine Chemistry, vol. 130, no. 6, pp. 522527, 2009.

[50] S. Tu, T. Li, Y. Zhang et al., "New reaction of Schiff base with dimedone: new method for the acridine derivatives under microwave irradiation," Journal of Heterocyclic Chemistry, vol. 44, no. 1, pp. 83-88, 2007.

[51] W. Shen, L.-M. Wang, H. Tian, J. Tang, and J.-J. Yu, "Brønsted acidic imidazolium salts containing perfluoroalkyl tails catalyzed one-pot synthesis of 1,8-dioxo-decahydroacridines in water," Journal of Fluorine Chemistry, vol. 130, no. 6, pp. 522527, 2009. 
[52] A. Nakhi, P. T. V. A. Srinivas, M. S. Rahman et al., "Amberlite IR-120H catalyzed MCR: design, synthesis and crystal structure analysis of 1, 8-dioxodecahydroacridines as potential inhibitors of sirtuins," Bioorganic and Medicinal Chemistry Letters, vol. 23, no. 6, pp. 1828-1833, 2013.

[53] Q. H. To, Y. R. Lee, and S. H. Kim, "Efficient one-pot synthesis of acridinediones by indium(III) triflate-catalyzed reactions of $\beta$ enaminones, aldehydes, and cyclic 1,3-dicarbonyls," Bulletin of the Korean Chemical Society, vol. 33, no. 4, pp. 1170-1176, 2012. 

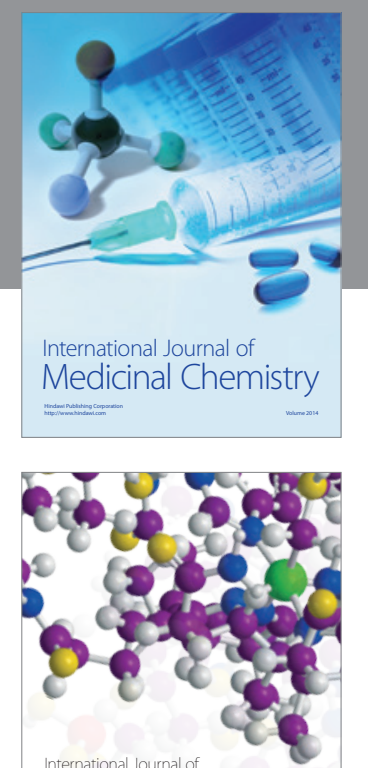

\section{Carbohydrate} Chemistry

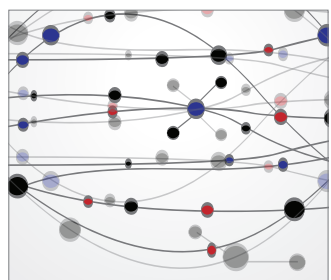

The Scientific World Journal
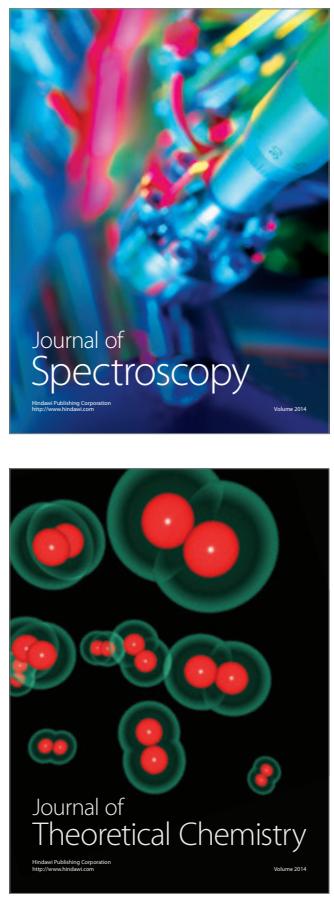
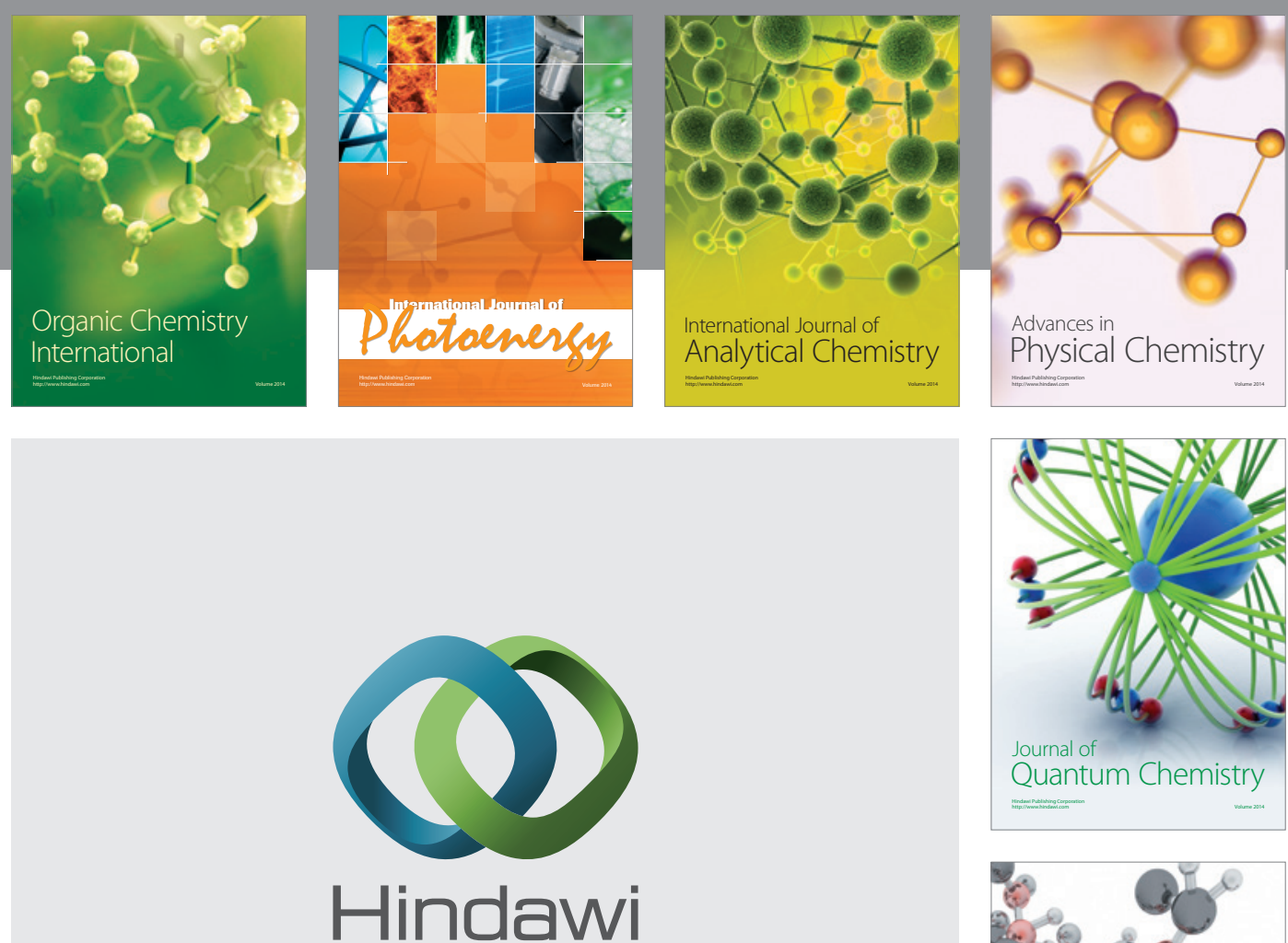

Submit your manuscripts at

http://www.hindawi.com

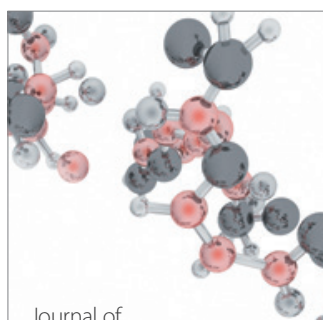

Analytical Methods

in Chemistry

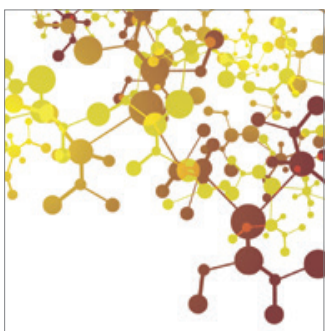

Journal of

Applied Chemistry

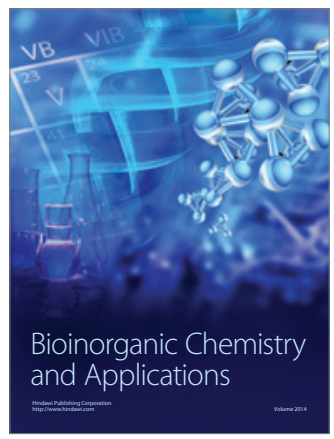

Inorganic Chemistry
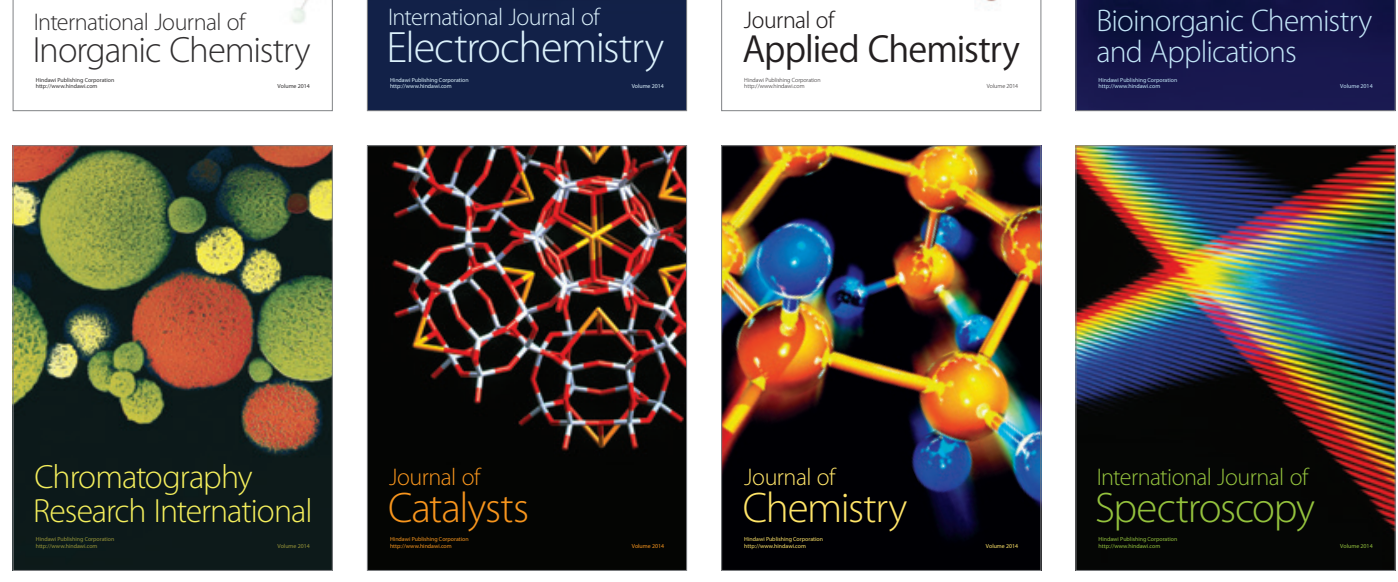